\title{
赤外線反射スペクトルによる嬏構造の定性的検討
}

\author{
高嶋広夫・加藤帨三 \\ (名古屋工業技術試験所)
}

\section{Studies on Structure of Sillicate Glaze by Infrared Reflection Method}

\author{
By \\ Hiroo TAKASHIMA and Etsuzo KATO \\ (Goverment Industrial Research Institute, Nagoya, Nagoya)
}

The structure of silicate glaze was studied by infrared reflection method.

The results obtained were as follows:

1. The main reflection peak (about $1100 \mathrm{~cm}^{-1}$ ) of silicate glasses shifted to lower wave number with the increse of content of basic and aluminium ions contained in the glass structure.

The effect of alkali, alkali earths, and aluminium ions on the $\mathrm{Si}-\mathrm{O}$ bond shift became more remarkable with the increase of ionic valency and radius.

The causes of shift to lower wave number of the infrared reflection peak were considered to be as follows.

a. By the electrostatic interaction between cation and oxygen atom, the Si-O bond strength was decreased in the silicate glass structure as compared with silica glass.

b. The increase of number of cation in the structure of silicate glass extends the mean Si-O linkage of random network, and lengthens the atomic distance of $\mathrm{Si}-\mathrm{O}$ bond, therefore weakens the Si-O field strength.

2. The cation entered into the structure of silicate glass broaded the peak, because the cation extends the network structure and consequently the field strength of Si-O bond becomes random.

That effect increases with the increase of electrostatic interaction between cation and oxygen atom.

3. The peak shifts to lower wave number, with the increase of number of cation in the structure of silicate glass.

But in the case of precipitating crystal in the glaze, wave number shifted to higher, for the reason that the effect of crystallization is dominant to peak shift and the field strength of $\mathrm{Si}-\mathrm{O}$ bond increases.

[Received Feb. 25, 1970]

\section{1. ま}

赤外線スペクトルでガラス状態の構造老探求しようと する試みは 1930 年代にはじまり，現在までにかなり多 数の報告がある。それらによると珪酸では結晶，ガラス を問わず SiーOの伸緮振動で女る最も顕著なピークは， $1100 \mathrm{~cm}^{-1}$ 付近に現われる。このピータ㤬酸構造中に いるいるな原子また快ンを導人寸るとそのピークは 低波数側にシフトすることが明らかにされている。

しかしながらこの種の研觉は二成分系，三成分系の報

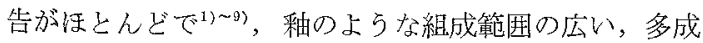
分にわたる報告はない。釉の構造はガラスと全く同じで あるが，特に原料の一つに長石を使用するのが常識であ るので，アルミナ分の導入量が一般ガラスより多くな
り，そのことが釉の性質を大きく左右する因子の一つと なっている。また釉に执いてはガラス相中に析出した結 晶相を含むことがしばしばあり，その現象を無視できず 同時にあつかわなければならない。このよらに釉は一般 ガラスより性状の変化比をむのがえられやすいとい え，ガラス構造を検討するには，いるいるな情報が多く えられるなど，むしろ陶磁器の釉を対象しすることは有 利なことであるら。

このよらな陶磁器の釉についてその性状を考えると き，その複雑さから X 線回折などで内部構造の情報を 適確に知ることがむずかしいが，赤外線スペクトルでは かなり適切に知ることができると思われ，それによって 広範囲に釉を検討しておくことは意味のあることである 
Table 1. Chemical composition of materials.

\begin{tabular}{|c|c|c|c|c|c|c|c|c|c|}
\hline \multirow{2}{*}{ materials } & \multicolumn{9}{|c|}{ Components } \\
\hline & $\mathrm{SiO}_{2}$ & $\mathrm{Al}_{2} \mathrm{O}_{3}$ & $\mathrm{Fe}_{2} \mathrm{O}_{3}$ & $\mathrm{MgO}$ & $\mathrm{CaO}$ & $\mathrm{K}_{2} \mathrm{O}$ & $\mathrm{Na}_{2} \mathrm{O}$ & Igloss & Tatal \\
\hline Miyagawa kalium feldspar & 67.07 & 16.89 & 0.54 & 0.12 & 0.22 & 14.85 & 0.88 & 0.19 & 100.76 \\
\hline Korea sodium feldspar & 71.38 & 16.14 & 0.26 & 0.13 & 0.89 & 0.21 & 9.58 & 1.35 & 99.82 \\
\hline Korea kaolin & 42.19 & 34.26 & 1.09 & 0.32 & 1.08 & 0.36 & 0.51 & 19.28 & 99.09 \\
\hline Fukushima quartz & 98.62 & 0.56 & 0.03 & 一 & 0.39 & 0.05 & 0.28 & 0 & 99.93 \\
\hline Nezumi limestone & 0.40 & 0.20 & 0.02 & 0.04 & 55.05 & 0.05 & 0.20 & 43.80 & 99.76 \\
\hline
\end{tabular}

う。したがって本報告では, まず缸磁器の高火度釉につ いてアルミナ成分や塩基性成分が婇の構造に与光る影響 について，主に $1100 \mathrm{~cm}^{-1}$ 付近俔われるピークの波形 およびシフトと組成との関係を検討し，定量的な考察も 加光てみた。

\section{2. 実 験 方 法}

\section{1 組 成 範 囲}

陶磁器の釉は珪酸塩系が多いが，低い焼成温度に用い る釉の場合は嶰珪酸塩系もある。しかし本報告は主に高 火度釉を扱ったため，俗に石灰婇と呼ばれる珪酸塩系の 組成を中心に検討した。試験した組成範囲注 $\mathrm{SiO}_{2}$ 孝枠 外に 1 モルに一定にし，図-1に示すようなダイヤグラ ムの範围で行なった*1. 図中右下方の空白な部分はアル カリ源として長石のみを用いたので，アルカリ分とアル ミナ分のバランスの関係上配合不可能な部分である。 た一定組成比でアルカリ拉よびアルカリ上類のみ置換し た場合についても検討した。

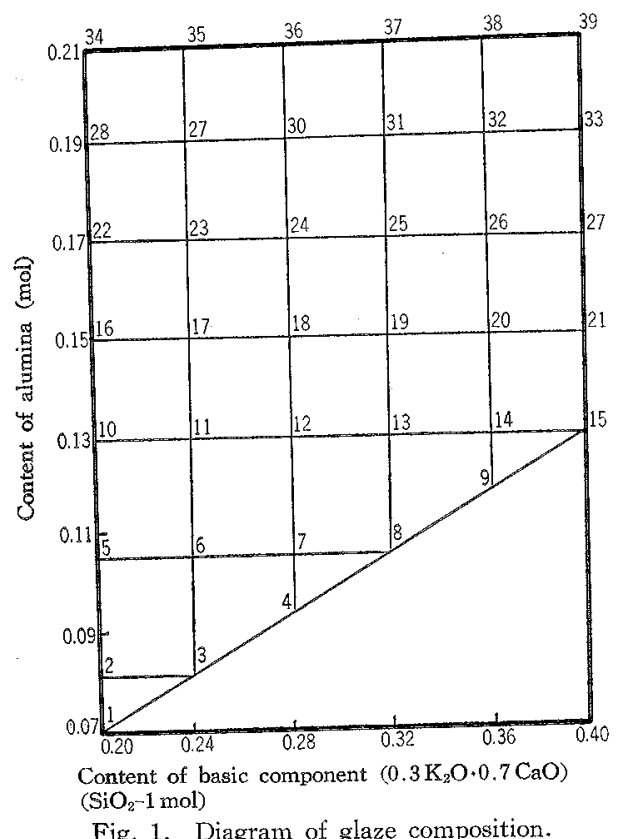

\section{2 原料}

実験に用いた原料は長石として岐阜県産の宮川カリ長

*1 普通，釉の化学式注塩基性成分を合計 1 モルにするのが習 慣であるが，この場合は $\mathrm{SiO}_{2}$ を1モルに一定にした。
Table 2. Content of alkali earth materials.

\begin{tabular}{|c|c|c|}
\hline & Main element $(\%)$ & Impurities \\
\hline Barium Carbonate & $\mathrm{BaCO}_{3} 98.9$ & $\begin{array}{l}\mathrm{SO}_{4} 0.12, \mathrm{SO}_{0.02} \\
\mathrm{Fe} 0.007, \mathrm{Na}_{2} \mathrm{CO}_{3} 0.41, \\
\mathrm{CaCO} 0.02, \text { absorbed } \\
\text { water } 0.13\end{array}$ \\
\hline Strontium Carbonate & $\mathrm{SrCO}_{3} 94.0$ & $\begin{array}{l}\mathrm{BaCO}_{3} 1.22, \mathrm{CaCO}_{3} 0.87, \\
\mathrm{Fe} 0.02 \text {, insoluble } \\
\text { impurities by } \mathrm{HCl} 2.45\end{array}$ \\
\hline $\begin{array}{l}\text { Basic Magnesium } \\
\text { carbonate }\end{array}$ & $\begin{array}{l}\mathrm{MgCO}_{3} 61.48 \\
\mathrm{Mg}(\mathrm{OH})_{2} 13.25 \\
\mathrm{CaCO}_{3} 8.40 \\
\mathrm{H}_{2} \mathrm{O} 15.17\end{array}$ & $\begin{array}{l}\mathrm{SiO}_{2} 0.132, \mathrm{Fe}_{2} \mathrm{O}_{3} 0.052, \\
\mathrm{Al}_{2} \mathrm{O}_{3} 0.058 \text {, } \\
\text { absorbed water } 2.02\end{array}$ \\
\hline
\end{tabular}

石，朝鮮ソーダ長石を使用した。これ社化学分析および $\mathrm{X}$ 線回折の結果, かなり純度のよい正長石であり, 曹 長石であることを確めた。そ机福島珪石，朝鮮カオリ ン。単石灰石を用いケが，これらのX線回折の結果蛙， それぞ石英，八口イサイトとメタ八ロイ立イトの混合 物, カルサイトであった。また炭酸入卜ロンチウム，炭 酸バリウムは堺化学工業（株）の工業薬品, 塩基性炭酸 マグネシウム法山化学工業（株）の工業薬品を用いた が，䋠度上充分使用できるものである。これらの分析値 および含有量を表 -1 ，表- 2 に示した。

\section{3 試料の作成と赤外線スペクトルの測定}

試料峘普通陶磁器を作る手法で行なった。すなるち正 径 $4 \mathrm{~cm}$ の素焼きした円板素地に施釉して。1300 ${ }^{\circ} \mathrm{C}$ 酸化 焰で炭化珪素発熱体を用いた電気宰で焼成した。赤外線 スペクトルの測定は，日立 EPI-G 型で空気を媒体とし た入射角 $60^{\circ}$ の1回反射法で行なった。珪酸塩の結晶の 赤外線スペクトルによる観察は今まで透過法によって行 なわれることが多かったが，近年ガラスなどの観察につ いて反射法が多くとりあげられて扮り，このようにガラ 又質を赤外線スペクトルで検討寸る場合は反射法に 10 の利点がある。透過法では試料の擪さによって干涉など を起す抢それがあるが，反射法で怯試料の厚さに無関係 なスペクトルがえられること，また透過法では常に吸収 と反射の 2 つ現象が重なって現われ試料の愿さや，女 るいは粘子の大きさが重要な因子となって人ってくる が，反射法で汇反射という1つの現象のみで解秎すれば よい，また釉などを検討する場合，非破壞試料でる測定 できることが大きな利点となる. 本実験に扔いても, 反 射法は $1100 \mathrm{~cm}^{-1}$ 付近に現われる反射ピークは透過法の 吸収ピークと同じ位置にありここれついて $\operatorname{Simon}^{109}$ は赤外線の斜め入射角度で試料の赤外線スペクトルを測 定したとき。媒質より大きな屈折率老もつ試料での反射 
は吸収の大きな位置で反射率が高くなると述べている。 本研究に抒ける釉はもちろ几空気との屈折率の差が充分 大きいため，ATR 法などによらなくとも直接 1 回反射 法で充分であり，反射法性むしち透過法にくらべてピー クが鋭敏で，その波形やシフトを観察寸るには，粒子の 散乱などの影響のある透過法より有利な万法といえる。 武料で表面が滑らかでない場合は研磨した。試料はある 程度以上に梁く研磨与ると，素地成分の昖散の影響があ らわれるが，厚く施釉した釉面で表面を滑らかにする程 度の仾磨では，研磨した試料としない試料で法注とんど 同じスペクトルが党られた。

\section{3. 実験結果亡考察}

\section{1 ピークの波形およびシフトの定性的観察}

\section{1 .1 アルミナ成分と塧基性成分量の変化の影響} いろいろな組成の釉, たと立ば図-2 に示寸ような, (1) $\mathrm{SiO}_{2}$, (2) $0.20\left(0.3 \mathrm{~K}_{2} \mathrm{O} \cdot 0.7 \mathrm{CaO}\right) 0.07 \mathrm{Al}_{2} \mathrm{O}_{3}$ 。 $\mathrm{SiO}_{2}$, (3) $0.20\left(0.3 \mathrm{~K}_{2} \mathrm{O} \cdot 0.7 \mathrm{CaO}\right) 0.13 \mathrm{Al}_{2} \mathrm{O}_{3} \cdot \mathrm{SiO}_{2}$, (4) $0.40\left(0.3 \mathrm{~K}_{2} \mathrm{O} \cdot 0.7 \mathrm{CaO}\right) 0.13 \mathrm{Al}_{2} \mathrm{O}_{3} \cdot \mathrm{SiO}_{2}$ の組成の 釉の赤外線反射スペクトルを測定してみると，珪酸四面 体に上る $1100 \mathrm{~cm}^{-1}$ 付近のピーク驻珪酸分以外の添加物 に上って低波数側にシフトする. 図中（1）结石英ガラ スであるが，この反射ピーク注ほほ $1120 \mathrm{~cm}^{-1}$ であっ た.こ札数多の文献によるデータと一致する ${ }^{1>21}$.

（2）はアルミナ分および塩基性成分ともに少ない透明 釉であるが，石英ガラスにくらべて低波数側にシフトし ている. (3) は (2)上りアルミナ分が増加した透明釉 であり，(4) はさらに塩基性成分を増加した透明婇で ある。このように $\mathrm{Si}-\mathrm{O}$ 振動による赫外線スペクトル は，珪酸塩ガラス中にアルミナ分や塩基性成分を導人す ることにより低波数側にシフトする。またそれらの導入



Fig. 2. Infrared reflection spectra of various glazes.
はピーク幅も広くすることがわかる、これらの実験結果 を検討するについての基本的な考え方をつぎの 3 つの項 に示し、これによって考察を行なった。

（i）添加された陽イオンの酸素に刘する静電気的結 合力が珪素と結合している酸素の結合力に影響を执よぼ し， Si-O 䦎の結合を弱める。この效果注結晶に関する Pauling の第 1 法則から荷電数が大きいほど，またイオ ン半径が小さいほど大きい。

(ii) 添加された陽イオンが珪酸四面体の網目構造を 押し拡げ開放構造孛助長して $\mathrm{Si}-\mathrm{O}$ 間の平均值としての 結合力を弱める.この効果致 2 価と 1 価イオンでは 2 価 の方が大きく, 同じ荷電数であれば，イオン非径が大き いほど大きい。

(iii）ピーク幅の拡がりは，添加される陽イオンが不 規則構造を助長して Si-O 間の距離が統計的にばらつく ことによって起る。これ政酸素に対する静電気的結合の 強さからイオン半径の小さいイオンほど大きい。

このような考え方をすれば，珄酸塩ガラスでアルミナ 分や塩基性成分を導入することによって石英ガラスの $\mathrm{Si}-\mathrm{O}$ 間の結合が弱められてピークは低波数側にシフト し, 不規則構造が助長されて $\mathrm{Si}-\mathrm{O}$ 間の距離のばらつき が多くなり，ピーク幅が拡がることがよく説明できる。

\section{1 .2 塩基性成分の置換によるピークのシフト}

3.1.2.1 アルカリ間の置換とピークのシフト 図-3 は一定組成 $0.20\left(0.3 \mathrm{R}_{2} \mathrm{O} \cdot 0.7 \mathrm{CaO}\right) 0.07 \mathrm{Al}_{2} \mathrm{O}_{3} \cdot \mathrm{SiO}_{2}$ で $\mathrm{R}_{2} \mathrm{O}$ を $\mathrm{K}_{2} \mathrm{O}$ と $\mathrm{Na}_{2} \mathrm{O}$ 亿置喚した場合の赤外線反射 スペクトルである・ピークのシフトはこの置換ではほと んど差がない上うであるが，やや $\mathrm{Na}_{2} \mathrm{O} の$ 方がピークが 低波数側であった.このことはイオン半径の小さいナト リウムの方が酸素を引きつける力が強いので，ピークは カリウムより低波数の方向にシフトさせる効果が岁るも のと思われる。一方イオン半径驾大きいカリウムはナト リウムより網目構造を押し拡げる効果は大きく，その面 からはカリウムはナトリウムよりピークを低波数側にシ

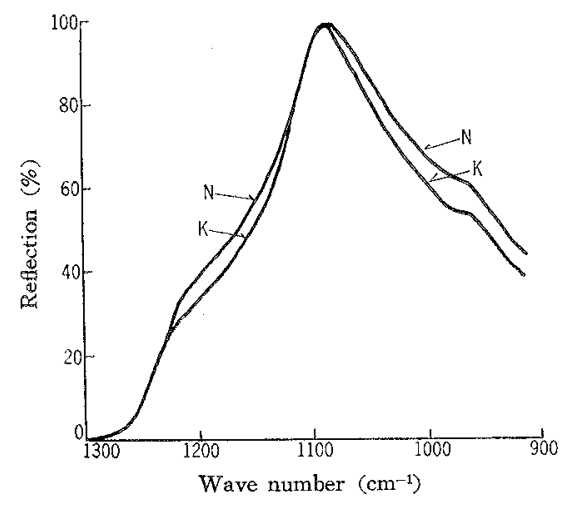

Glaze composition

$\mathrm{K}: 0.20\left(0.30 \mathrm{~K}_{2} \mathrm{O} \cdot 0.70 \mathrm{CaO}\right) 0.07 \mathrm{Al}_{2} \mathrm{O}_{3} \cdot \mathrm{SiO}_{2}$ $\mathrm{N}: 0.20\left(0.30 \mathrm{Na}_{2} \mathrm{O} \cdot 0.70 \mathrm{CaO}\right) 0.07 \mathrm{Al}_{2} \mathrm{O}_{3} \cdot \mathrm{SiO}_{2}$

Fig. 3. Effect of alkali variation in the glaze. 
フトさせる効果があるとみなけれ壮ならない，その相反 寸る方向の効果はどちらが大きいかを検討しなくて岋な らないが，実際のシフト量岋ナトリウムの方がカリウム よりやや大きいといら実験結果から判断して，1 俩イオ ン間の置換で法静等気的效果の方が，構造の押し拡げの 効果を上まわっていると思われる。

3.1.2.2 アルカリ土類間の置換とピークのシフト 図-4 注一定組成 $0.20\left(0.3 \mathrm{~K}_{2} \mathrm{O} \cdot 0.7 \mathrm{RO}\right) 0.106 \mathrm{Al}_{2} \mathrm{O}_{3}$ 。 $\mathrm{SiO}_{2}$ で $\mathrm{RO}$ を $\mathrm{MgO}, \mathrm{CaO}, \mathrm{SrO}, \mathrm{BaO}$ と置換した場 合の赤外線反射スペクトルで，この場合はイオン半径が 大きくなるにしたがって波数任低い方にシフトした。ア ルカリ士類間の置搰については, 先のアルカりとは異な ってイオン半径が大きくなるにしたがって，かなり顕著 にピークは低波数側にシフトする。これ忙 2 価イオン間 の置換ではイオン半径が大きくなるにしたがって構造を 押し抎げ，全体として Si-O 間の結合を弱める効果が， 他方のイオン半径が大きくなるにつれて酸素に働く静䨘 気的引力が弱くなり $\mathrm{Si}-\mathrm{O}$ 間の結合を弱力る效果が減少 するといら效果を上まわっていると考えなければならな い.このよらに静晸気的效果と, 批し抬げの効果はアル カリ間のイオン置俩とアルカリ土類閒のイオン镇換では 差違があり，アルカリ士類間の埴換法アルカリ間の㯰換 にくらべて押し拡げの効果が強く現われる。その効果の 理由法次の上5に考えられる. 寸なわち $\mathrm{Na}^{+}(0.98 \AA)$ $\rightarrow \mathrm{K}^{+}(1.33 \AA)$ の置換と $\mathrm{Ca}^{2+}(1.06 \AA) \rightarrow \mathrm{Ba}^{2+}(1.43 \AA)$ の置換で，イオン半径差は 2 つ置掺ともほぼ同じと考 えられる。ナトリウムとカルシウムで陽イオンが Si-O 閒定結合している酸素を引きつける力は荷電数の大きい カルシウムの方が約 2 倍強い, そこで, $\mathrm{Na}^{+} \rightarrow \mathrm{K}^{+}$と $\mathrm{Ca}^{2+} \rightarrow \mathrm{Ba}^{2+}$ の置換考考えてみた場合, どちらがイオン 半径の增大によって Si-O の原子間距離を長くするかの 押し㹡げの効果法, 当然 $\mathrm{Si}-\mathrm{O}$ 間の結合が静電気的に弱 まっている 2 価イオン間の置換の方が大きい。したがっ て先に述べた基本的な考方方を合わせて考察すれば， 1



Fig. 4. Effect of alkali earth variation in the glaze.
価イオン間の置換では静電気的引力の効果の方が若干強 く観測され． 2 価イオン間の置換では押し拡げの効果の 方が法るか強く現われるといえよら。

3.1.2.3 アルカリ，アルカリ土類の䄄互関係 アル カリとアルカリ土類の違いをさらに調らべるために网者 の置換による実験を行なった。戝一5，6，7，8 は一定組 成 $0.25\left(x \mathrm{R}_{2} \mathrm{O} \cdot y \mathrm{RO}\right) 0.10 \mathrm{Al}_{2} \mathrm{O}_{3} \cdot \mathrm{SiO}_{2}$ で $\mathrm{K}_{2} \mathrm{O}$ と $\mathrm{BaO}$,

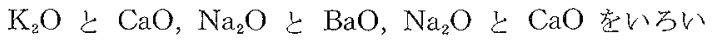
ろな割合に置換した赤外線スペクトルである。 $\mathrm{K}_{2} \mathrm{O}$ と $\mathrm{BaO}, \mathrm{Na}_{2} \mathrm{O}$ と $\mathrm{BaO}$ の置換では $\mathrm{BaO}$ 量の多い方が若 干低波数側にシフトする。また $\mathrm{BaO}$ 量の多い方が 1200 $\mathrm{cm}^{-1}$ 付近のふくら多が大き，960 $\mathrm{cm}^{-1}$ に現われるピ 一クの眉の高さが大きくピーク愊が広い。 $\mathrm{K}_{2} \mathrm{O}$ と $\mathrm{CaO}$, $\mathrm{Na}_{2} \mathrm{O}$ と $\mathrm{CaO}$ の置換で虫中心波数㧍よびピーク幅とも 大きく変化する.才な⿰ち $\mathrm{CaO}$ 量の多い加中心波数 が筒くピ一ク幅は広い。このよらにアルカリから $\mathrm{CaO}$ への置換とアルカリ加ら $\mathrm{BaO}$ に置換したとき汶, シフ ト执よびピーク幅ともに逆の方向に效果起和よぼすこと

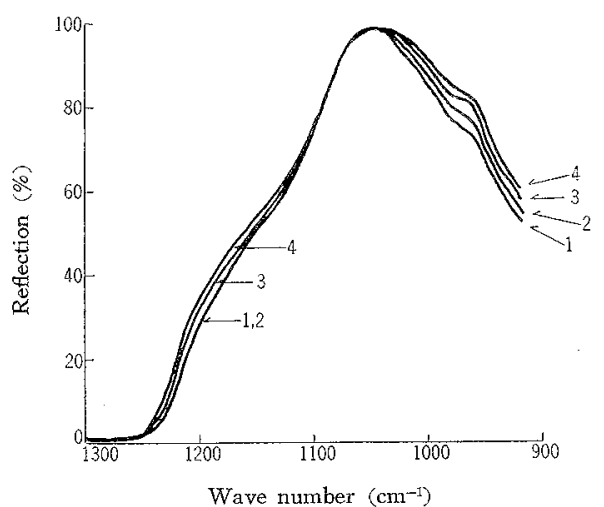

Glaze composition $0.25\left(x \mathrm{~K}_{2} \mathrm{O} \cdot y \mathrm{BaO}\right) 0.1 \mathrm{Al}_{2} \mathrm{O}_{3} \cdot \mathrm{SiO}_{3}$ $\begin{array}{lll}\text { 1. } x: 0.10 y: 0.15 & \text { 2. } x: 0.075 y: 0.175\end{array}$

Fig. 5. Effect of substitution of $\mathrm{BaO}$ for $\mathrm{K}_{2} \mathrm{O}$ in the glaze.



Glaze composition $0.25\left(x \mathrm{~K}_{2} \mathrm{O} \cdot y \mathrm{CaO}\right) 0.1 \mathrm{Al}_{2} \mathrm{O}_{3} \cdot \mathrm{SiO}_{2}$ $\begin{array}{ll}\text { 1. } x: 0.10 y: 0.15 & \text { 2. } x: 0.075 y: 0.175\end{array}$ $\begin{array}{lll}\text { 3. } x: 0.05 y: 0.20 & \text { 4. } x: 0.025 y: 0.225\end{array}$

Fig. 6. Effect of substitution of $\mathrm{CaO}$ for $\mathrm{K}_{2} \mathrm{O}$ in the glaze. 


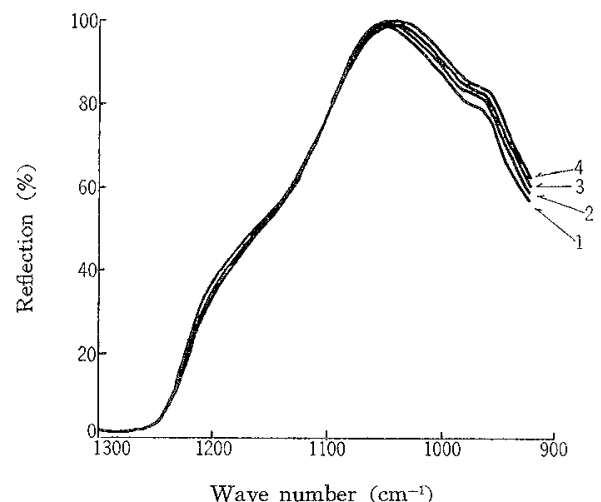

Glaze composition $0.25\left(x \mathrm{Na}_{2} \mathrm{O} \cdot y \mathrm{BaO}\right) 0.1 \mathrm{Al}_{2} \mathrm{O}_{3} \cdot \mathrm{SiO}_{2}$ $\begin{array}{ll}\text { 1. } x: 0.10 y: 0.15 & \text { 2. } x: 0.075 y: 0.175\end{array}$ $\begin{array}{ll}\text { 3. } x: 0.05 y: 0.20 & \text { 4. } x: 0.025 y: 0.225\end{array}$

Fig. 7. Effect of substitution of $\mathrm{BaO}$ for $\mathrm{Na}_{2} \mathrm{O}$ in the glaze.



Glaze composition $0.25\left(x \mathrm{Na}_{2} \mathrm{O} \cdot y \mathrm{CaO}\right) 0.1 \mathrm{Al}_{2} \mathrm{O}_{3} \cdot \mathrm{SiO}_{2}$ $\begin{array}{ll}\text { 1. } x: 0.10 y: 0.15 & \text { 2. } x: 0.075 y: 0.175\end{array}$ $\begin{array}{ll}\text { 3. } x: 0.05 y: 0.20 & \text { 4. } x: 0.025 y: 0.225\end{array}$

Fig. 8. Effect of substitution of $\mathrm{CaO}$ for $\mathrm{Na}_{2} \mathrm{O}$ in the glaze.

に特に注目しなければならない。 $\mathrm{K}_{2} \mathrm{O} \rightarrow \mathrm{BaO}, \mathrm{Na}_{2} \mathrm{O} \rightarrow$ $\mathrm{BaO}$ で法アルカリ 2 原子に対してアルカリ土類 1 原子 が置換するので， $\mathrm{BaO}$ が多くなるにしたがって，ガラ ス中の陽イオンの数は少なくなるが， $\mathrm{BaO}$ 量の多い方 が波数の低い方にシフトした，このことは1価イオンよ りも2 価イオンの方がいが構造を拥し拡㚈て $\mathrm{Si}-\mathrm{O}$ 間 の結合を弱める効果が大きいかをよく示している， $\mathrm{K}_{2} \mathrm{O}$ $\rightarrow \mathrm{CaO}, \mathrm{Na}_{2} \mathrm{O} \rightarrow \mathrm{CaO}$ では $\mathrm{CaO}$ 亿置撸していくこと に上り静電気的に，アルカリより Si-O閒の結合を弱好 る效果が大きいにも加わらずピークの波数注高い。こ

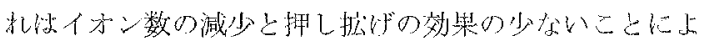

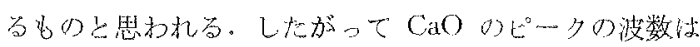
$\mathrm{Na}_{2} \mathrm{O}, \mathrm{K}_{2} \mathrm{O}, \mathrm{CaO}, \mathrm{BaO}$ の 4 者閒で注最も高波数側に あることはよく理解できよう。

\subsubsection{4 アルカリ, アルカリ土類の置換とピーク幅} ピーク愊の増加は一般に珪酸塩四面体網目構造の結合力 のげらつきの增大を意味するものと考えられるが，この 効果忺静電気的結合力の大きいもの注ざ大き加った。す なわちアルカリでは，図-3 のように $\mathrm{Na}>\mathrm{K}$ の順で女
り、これはナトリウムの方がカリウムよりイオン半径が 小さいためであると思われる。アルカリ土類で注図-4 の上らに $\mathrm{Ca}>\mathrm{Sr}>\mathrm{Ba}$ の順にピータ愊翟広く、これ も明らか炕イオン半径の小さいものほゼ広い。また図一3 加ら図-8で，アルカリ，アルカリ上類を総じて観察す ることができ， $\mathrm{CaO}$ が最もピーク愊が広く $\mathrm{BaO}, \mathrm{Na}_{2} \mathrm{O}$ ， $\mathrm{K}_{2} \mathrm{O}$ の順となる。このように幅の拡がりに㧍よぼす效


がわかった。

以上 3.1.2の項で述べたように釉としてのガラス構造 中において塩基性成分としてのアルカリ，アルカリ土類 の差遥が赤外線スペクトルで注っきり区别できる。ア ルカリをしての $\mathrm{Na}_{2} \mathrm{O}$ と $\mathrm{K}_{2} \mathrm{O}$ の差は赤外線スペクトル でも少ないし，アルカリ上類では, $\mathrm{MgO}, \mathrm{CaO}, \mathrm{SrO}$, $\mathrm{BaO}$ と差注大きい。このこと注実際の釉の性状，例党 壮透明釉定作る場合, アルカリ間の置換では。多少 $\mathrm{Na}_{2} \mathrm{O}$ の片出 $\mathrm{K}_{2} \mathrm{O}$ 上り低い烧成湿度で光沢透明嬏とし ての組成籍国名広いといわれているが，西专り变化はな いのが常識である・アルカリ士類間の置換では $\mathrm{MgO}$ 怕 組成的心透明簕围が狭く, $\mathrm{CaO}$ が透明婇を作る場合最 も作り易い， $\mathrm{SrO}, \mathrm{BaO}$ でも $\mathrm{CaO}$ を塩基性成分の主体 にした不庅婇注ど透明婇としての安定性に欠ける。この ようにアルカリ上類間の置換は嬏の性状を大きく変える ことが普通である。したがって婇組成と赤外線スペクト ルのピークのシフトとピーク幅は関連性が大きいことが みとめられたので，この報告は今後，釉性状を解析する 1つの手懸りとなりらるものと考える.

\subsection{3 釉中に結晶が析出した場合}

この系の契験で嬏印組成としてアルミナ分を増加して いくと，灰長石の結晶が析出する。均一なガラス相でア ルミナ分の導入はピークの波数を低い方にシフトさせた が，この上うに嬏に結晶が析出すると，その点より波 数はかえって高い方にシフトする. 同じ現象について，

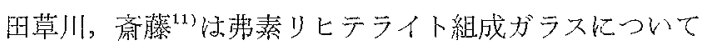
結晶析出と同時にピークの波数注高い方にシフトするこ と起報告している。図-9 亿示すよらな（No.6） 0.24 $\left(0.3 \mathrm{~K}_{2} \mathrm{O} \cdot 0.7 \mathrm{CaO}\right) 0.11 \mathrm{Al}_{2} \mathrm{O}_{3} \cdot \mathrm{SiO}_{2}$, (No. 11) 0.24 $\left(0.3 \mathrm{~K}_{2} \mathrm{O} \cdot 0.7 \mathrm{CaO}\right) 0.13 \mathrm{Al}_{2} \mathrm{O}_{3} \cdot \mathrm{SiO}_{2}$, (No. 17) 0.24 $\left(0.3 \mathrm{~K}_{2} \mathrm{O} \cdot 0.7 \mathrm{CaO}\right) 0.15 \mathrm{Al}_{2} \mathrm{O}_{3} \cdot \mathrm{SiO}_{2}$ の組成で No, 6, No. 11, No. 17 と $\mathrm{Al}_{2} \mathrm{O}_{3}$ の含有㟟が增加ずるが, No.

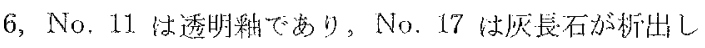

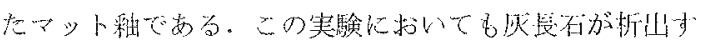
るとピークの波数惊滈い方にシフト寸る現象がみられ た.すなかちガラス棈造中に原子間距離の短い結晶構造 が存在することによって，釉全体の $\mathrm{Si}-\mathrm{O}$ 結合の強さが 強固になることを示していると考えられる。これを確認 するために，図-9 の No. 17 の試料を誂料の焼成最高 温度で急冷して結晶が析出しない嬏を作り，徐泠して綘 


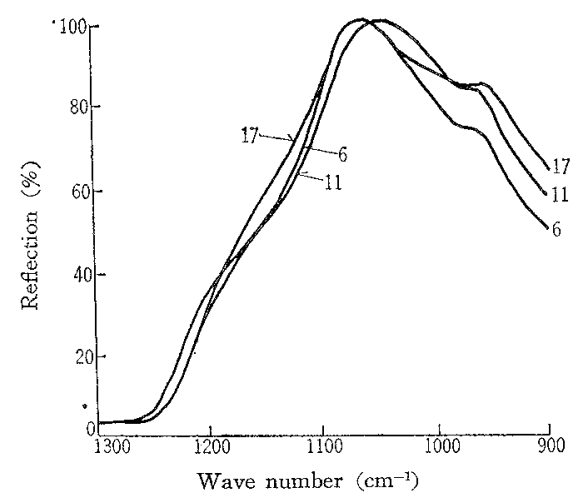

Glaze composition

$6: 0.24\left(0.3 \mathrm{~K}_{2} \mathrm{O} \cdot 0.7 \mathrm{CaO}\right) 0.11 \mathrm{Al}_{2} \mathrm{O}_{3} \cdot \mathrm{SiO}_{2}$

$11: 0.24\left(0.3 \mathrm{~K}_{2} \mathrm{O} \cdot 0.7 \mathrm{CaO}\right) 0.13 \mathrm{Al}_{2} \mathrm{O}_{3} \cdot \mathrm{SiO}_{2}$

$17: 0.24\left(0.3 \mathrm{~K}_{2} \mathrm{O} \cdot 0.7 \mathrm{CaO}\right) 0.15 \mathrm{Al}_{2} \mathrm{O}_{3} \cdot \mathrm{SiO}_{2}$

(No. 17: mat glaze)

Fig. 9. Effect of crystallization in the glaze.

奛が析出した釉の赤外線反射スペクトルと比較したと き，急冷試料はピ一クの中心波数㕶低い，急冷試料怙高 温構喈のためピークの波数が低くなるとも考えられる が，この系の透明釉試料で急冷，徐冷によるピークのシ フトはほとんどなかった。このことから啋中に灰長石が 析山寸ることは，波数索高い加にシフトさせるといらこ とになる、をた雨試料のX 線回折学行なって，徐泠試

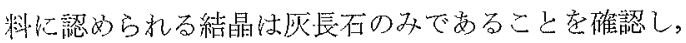
さらに顕微鏡で結晶を観察し, その面積比で徐冷試料の 兏長石の量を推定すると約 $30 \%$ 析出しており，ピーク のシフト恄晶のピークで支配されると思われる・同様 に急泠試料で将灰長石の析出は僅少であることを確め to.

\section{2 組成淁化とシフト量についての定量的考察}

\section{2 .1 ピークシフトにおけすアルミナ分の効果}

図-10（a）注図-1 に示した笑験範围に抒いて 1100 $\mathrm{cm}^{-1}$ 付近に存在する $\mathrm{Si}-\mathrm{O}$ 振動のアルミナ分の影響孛 示した図である。この組成範团で最も波数が高いのは No. 1 であって，1090 $\mathrm{cm}^{-1}$ であった。図で明らかなよ うにアルミナの含有量が増加するにしたがって波数は低

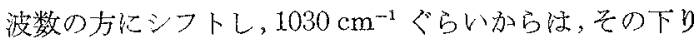
方は非常に少なくなる。数本の曲線で線間注図一-1 と刘 照してわかるよ 5 に, 塩基性成分の効果量である。この 一遭の釉についてアルミナ分および熄基性成分のピーク

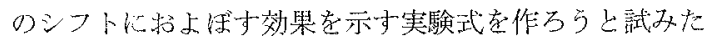
が，アルミナの效果老諾ベる場合，アルミナ分以外を一


ばよいが，石死釉場合アルミナ分を多量飞増加させる と必时マット糔となるので広範囲にわたって光沢透明釉 としての效果を調べるわけにはいかない，そのとき塩基 性成分を，さらに増加すると透明釉としてのアルミナ分 の添加量が多くと机る.しかしピークの中心波数忹塩基 性成分を添加しただけ低くなるが，添加したときとしな



(a)

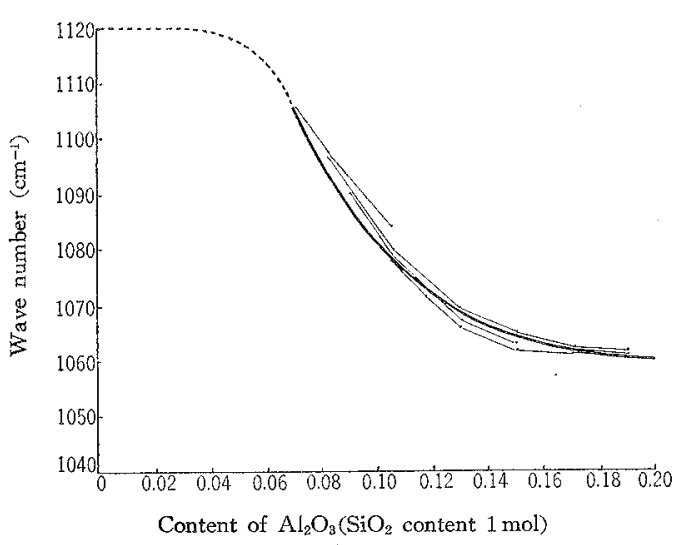

(b)

Fig. 10. Reflection of peak shift at around $1100 \mathrm{~cm}^{-1}$ in the silicate glaze with the increase of $\mathrm{Al}_{2} \mathrm{O}_{3}$ contents.

いときのシフトの関係を示す曲線は，ほぼ同じ傾问にあ ったので塩基性成分の効果分だけ曲線定移動させて，ア ルミナ分の影響を示寸曲線とした。さらに実験によって 求めた溶融石英のピークの波数を $1120 \mathrm{~cm}^{-1}$ として（文

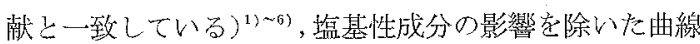
を桷くと図-10 (b) のよらになる。これをアルミナ分の


な叔 Al イオンのガラス構造中の位置至赤外線スペタト ルで観察するとさ,塩基性战分/アルミ十分のモル比が 1 より大きいときアルミニウムは珪素の位置に置換してガ ラス構造中で四配位をとり，Si-O-Alの振動となってピ 一クは低波数側にシフトし，末たその比が 1 よりさい ときは六配位になって，1100 $\mathrm{cm}^{-1}$ 付近のピークには直 接関与せず别の振動系となるが， $1100 \mathrm{~cm}^{-1}$ 付近の振動 壮とのときはかえって波数の高い方向にシフトするとい 


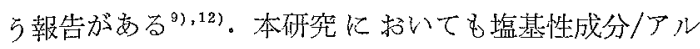
ミナ分の比は 1 より大きいのでアルミニウムイオンは四 配位をとる。事実われわれは蛍光 X 線によってアルミ ニウムイオンの配位数怯四配位と決定している。したが ってこの場合のシフトも $\mathrm{Si}-\mathrm{O}-\mathrm{Al}$ 振動によるものと考 えられる。

\section{3 .2 ピークシフトにおける塩基性成分の効果}

塩基性成分の効棵走示守曲線もアルミナ分について行 なったことと同じ操作をして，図-11 (a) 为ら図-11 (b) のような曲線を得ることができる。これをこの系の塩基 性成分の珪酸四面体の網目構造に拉よぼす效果とした。



Content of tasic component $\left(\mathrm{SiO}_{2}\right.$ constant $\left.1 \mathrm{~mol}\right)$ (a)

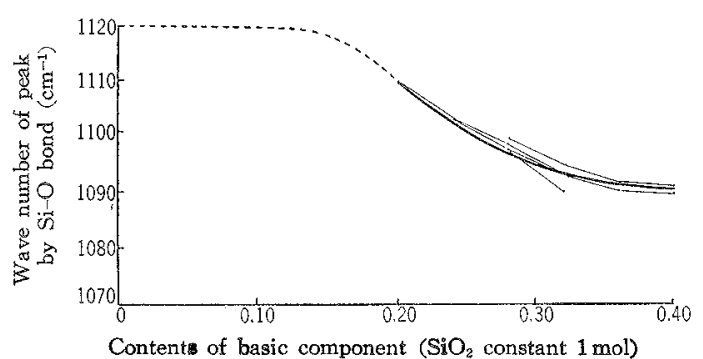

(b)

Fig. 11 Reflection of peak shift at around $1100 \mathrm{~cm}^{-1}$ in the silicate glaze with the increase of basic component contents.

\section{2 .3 波数計算の実験式の作成}

上に揭げた図-10 (b) と図-11 (b) の2つの曲線から， それに合致するような实験式を算出してみると，つぎの よらになった。

$$
\nu=1120-\left(64 e^{-1 / 2000 x^{3} *}+35 e^{-1 / 100 x^{3} * *}\right)
$$

$\nu$ 注各組成の求めようとする波数，1120 熔融石英の 中心波数， $x^{3 *}$ 壮アルミナの最（モル） $x^{3 * *}$ 注塩基性成 分 $\left(0.3 \mathrm{~K}_{2} \mathrm{O} \cdot 0.7 \mathrm{CaO}\right)$ の量（モル）である。な括 $\mathrm{SiO}_{2}$
Table 3. Calculated wave number by examination formula and observed wave number at each composition of glaze.

$\begin{array}{lllllllll}\text { glaze No. } & 4 & 7 & 12 & 18 & 11 & 13 & 14\end{array}$

$\begin{array}{llllllll}\text { calculated twave number } & 1067 & 1058 & 1045 & 1048 & 1049 & 1039 & 1035\end{array}$ $\begin{array}{lllllllll}\text { observed wave number } & 1063 & 1056 & 1046 & 1042 & 1052 & 1043 & 1040\end{array}$

は 1 モルに一定とする.この式で計算される波数の值と 実測とはかなりよく一致する。この例を表-3に揭げて 招く。

この実験式によって塭基性成分を $\left(0.3 \mathrm{~K}_{2} \mathrm{O} \cdot 0.7 \mathrm{CaO}\right)$ にした石扊嬏系については，波数のシフトについての動 间学知ることができ，今後㮰ついているいるな性質を 探求与る手懸となるう。

\section{4. 総括}


ルを用い，その構造や物性を探求寸る一つの手䦊りをえ 万目的で粙の組成変化と Si-O 振動による $1100 \mathrm{~cm}^{-1}$ 付 近のピークの波形とシフトを検討し，つぎのような結果 究衣。

1) 婇りような珪酸塩系ガラ火について，テルミナ分 や塩基性成分が尊入されると波数は低波数側にシフト し，ピークの愊も広くなる。これ恬釉全体の Si-O 結合 が導入された陽イオンによって弱められ，また不䙺則樥 造を㽖長寸ることを意味している。さらに石灰釉系につ いてのアルミナ分と塩基性成分の尊入量とシフトとの関 係について実験式を導いた。

2) Si-O-Si 結合について導入される陽イオンは，い ずれもそのピークを低波数側にシフトさせ，ピーク幅を 広げるが，その量関係はそれぞれのイオンによって異な る.すなわらシフトについて社導入される陽イオンの静 笔気的引力の效果と珪酸塩四面体の網目構造孛押し拡げ て Si-O間の結合定弱める效果があるが，アルカリ間の イオン置換壮静電気的効果分若干強く現われ，アルカリ 土類間の置换では，押し拡げの効果の方がかなり強く現 われる。総合して洘えて办るとアルミナ，アルカリ土 類, アルカリ類で荷電数が大きいほど，またイオン半径 が大きいほどシフトの效果壮大きい。

つぎに不規則棈造起助長してピーク愊を拡げる効果 は，陽イオンの静雪気的引打の強いもの汪ど大きい。し


とによって租の内部構造や状態堂梌討することができ 万.

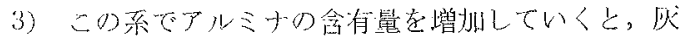
長石の絬晶が析出するが，結晶が析出すると，均一なが ラス相よりピークは高波数側になる。これは原子間喿離 の短い結晶が，ガラス相中に混人することによって，釉 全体のSi-O-Si 結合が強固になることを意味している。

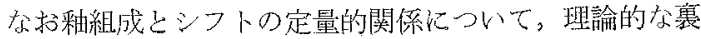


仆をしなかったが、今後そのことについて检討至加える つむりである。

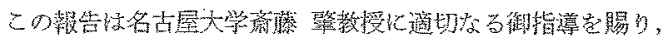

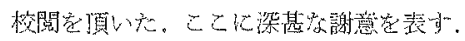

\section{文献}

1) I. Simon and H.O. McMahon, J. Am, Ceram. Soc. 36,160 (1953).

2) P.E. Jellyman and J.P. Procter, J. Soc. Glass Tech. 39, $173 \mathrm{~T}$ (1955).

3) D. Crozier and R.W. Douglas, Phys. Chem. Glasses 6, 240 (1965).

4) R.V. Adams, Phys. Chem. Glasses 2, 101 (1961).

5) Gouq-Jen Su. N.F. Borrelli and A.R. Miller, Phys.
Chem. Glasses 3, 167 (1962).

6) A.F. Pozubenkov and V.A. Florinskaya, The Struc. iure of Glass 7, 6 (1966).

7) E'F Cherneva and V.A. Florinskaya, The Structure of Glass 7, 14 (1966).

8) T.E. Chbotareva, The Structure of Glass 7, 21 (1966).

9) V.A. Kolesova, The Structure of Glass T, 34 (1966).

10) I. Simon, J. Optic Soc. Am. 41, 336 (1951).



12) Delbert E. Day and Guy E. Rindone, J. Am. Ceram. Soc. 45, 489 (1962).

(2/25/1970 受付) 